\title{
Development and Quality Evaluation of Chutney from New Varieties of White and Pink-Fleshed Guava
}

\author{
Homi Joshi $^{1 *}$, A. Kochhar ${ }^{1}$ and R.S. Boora ${ }^{2}$ \\ ${ }^{1}$ Department of Food and Nutrition, Punjab Agricultural University, \\ Ludhiana-141004, Punjab, India \\ ${ }^{2}$ Regional Fruit Research Station, Bahadurgarh, Patiala-147021, Punjab, India \\ *Corresponding author
}

\begin{tabular}{|l|}
\hline Ke y w o r d s \\
Chutney, Guava, \\
Nutritional \\
composition, \\
Sensory evaluation, \\
Varieties.
\end{tabular}

\section{Introduction}

Guava is considered as one of the most popular fruit of the tropical and subtropical regions of the world. It is a native of tropical America, and is now widely grown all over India. The most important guava growing states are: Maharashtra, Bihar, Madhya Pradesh, Uttar Pradesh, Chhattisgarh, Punjab and Haryana. Guava is also known as "poor man's apple" due to its high nutritive value and availability at an affordable price.
Being a good source of many nutrients such as dietary fiber, pectin, vitamin $\mathrm{A}$ and $\mathrm{C}$, folic acid, potassium, copper and manganese, guavas are often included among super fruits.

They also contain fair amount of calcium, phosphorus and iron. In terms of vitamin $\mathrm{C}$ content, guava ranks third after barbadose cherry and amla. Besides this, they also contains carotenoids, flavonoids particularly 
quercetin and other polyphenols (Joseph and Priya, 2011).

The ripe fruits are generally consumed in fresh form whereas, the surplus produce can be processed into various products like juice, nectar, jam, jelly, cheese, chutney, fruit bar or dehydrated and canned products. Chutney is a spicy relish of the Indian subcontinent made of fruits or vegetables, sugar, salt, spices and herbs. The product is prepared from peeled, sliced or grated unripe or semiripe fruit by cooking the shredded fruit with salt over medium heat for 5-7 min, mixing and then adding sugar, spices and vinegar. Cooking over mild heat is continued until the product appears in form of thick puree. The chutney is then filled hot in sterilized jars.

Although guava tree bear two crops in a year but guava fruits are highly perishable in nature and are available only for a very short duration. Thus, because of the limited shelf life, it is necessary to utilize the fruit for making different value added products to minimize the losses and stabilize the prices. In view of this, guava chutney has a great potential in the processing industry. Keeping all these aspects in view, the present study was planned with the objectives to standardize appropriate receipe for the preparation of guava chutney, and also to evaluate the nutritional composition of the chutney developed from newly developed varieties of white and pink-fleshed guava varieties.

\section{Materials and Methods}

The present study was carried out at the Department of Food and Nutrition, College of Home Science, Punjab Agricultural University, Ludhiana (Punjab) during the year 2015-2016. Mature fruits of six guava cultivars - Sardar, Shweta, Hisar Safeda that were white-fleshed and Lalit, Punjab Pink,
Hisar Surkha that were pink-fleshed were collected from Regional Fruit Research Station, Patiala, for the preparation of chutney.

\section{Preparation of chutney}

The fruits were washed in running water to remove dirt and dust particles. They were cut into pieces and seed core was removed. The slices were then ground by adding water to half volume of fruits in mixer grinder and the whole mass was obtained in the form of fine pulp. After getting the pulp, the requisite quantity of ingredients were added as per the recipe. To the fruit pulp $(500 \mathrm{~g})$, sugar $(500 \mathrm{~g})$ and salt $(10 \mathrm{~g})$ were mixed and the mixture was left for 20 minutes. To this mixture, onion $(50 \mathrm{~g})$, garlic $(5 \mathrm{~g})$ and ginger $(5 \mathrm{~g})$ paste was added and it was cooked on a low flame. Thereafter, coarsely ground spices like cardamom ( $2 \mathrm{~g})$, cinnamon $(2 \mathrm{~g})$, cloves $(2 \mathrm{~g})$, aniseed (2 g), cumin (2 g) and red chili powder $(5 \mathrm{~g})$ were added with continuous stirring while cooking. When the desired consistency has been reached vinegar $(40 \mathrm{ml})$ was added and it was further cooked for 2 minutes to obtain semi-solid guava chutney of uniform consistency. The products were poured hot into clean, dry and sterilized glass jars. Jars were corked after cooling and stored airtight. Care was taken to achieve accuracy in the quality and quantity of the ingredients, method of preparation, time, temperature and the number of portions.

\section{Sensory evaluation of the chutneys}

Organoleptic evaluation of the chutney developed from different varieties of white and pink-fleshed guava was carried out using 9 point Hedonic scale by a panel of ten semitrained judges (Larmond, 1977). The panelists evaluated the products for colour, taste, aroma, texture, flavour and overall acceptability to determine the most acceptable 
variety for the chutney. The products were then analysed for their nutritional composition.

\section{Nutritional analysis of the chutneys}

The standard method of AOAC (2000) was adopted for the determination of moisture, protein, fat, crude fiber and ash content while the total carbohydrate in the chutney was determined by difference (James, 1995). Minerals such as calcium, phosphorus and potassium were estimated using atomic absorption spectrophotometer (AAS, Varian model) after wet digestion (Piper, 1950). The ascorbic acid in the chutney was analysed colourimetrically at $500 \mathrm{~nm}$ as described by AOVC (1996) whereas total carotenoid content was measured using petroleum ether as extracting solvents and estimating the extract in UV/visible spectrophotometer at $450 \mathrm{~nm}$ (Zakaria et al., 1979).

\section{Statistical analysis of the data}

Sensory scores for the chutney developed from different guava cultivars were analysed using Kruskal Wallis test for selecting the best variety for the product. One way analysis of variance (ANOVA) was applied to compare the nutritional composition of the chutney prepared from six guava cultivars and $\mathrm{p}$ values $\leq 0.5$ were considered significant. The difference among the means was compared using Tukeys test. All statistical analysis was done using SPSS package programme version 17 .

\section{Results and Discussion}

\section{Organoleptic evaluation of guava chutney}

Organoleptic evaluation of chutney developed from different guava cultivars was carried out for which the scores are presented in Table 2 . It is apparent that the difference in scores for the chutneys prepared from different varieties of white and pink-fleshed guavas was found to be statistically significant for all the sensory parameters. Overall, the chutney developed from Sardar (white-fleshed) variety of guava had the highest sensory scores for appearance (7.80), colour (7.90), texture (7.75) and overall acceptability (7.73). Among the pink fleshed guava chutneys, Hisar Surkha scored highest in terms of appearance (7.30), colour (7.60), texture (7.45), flavor (7.55) and overall acceptability (7.48). Chutneys developed from other varieties were also liked at various degrees, although a little less than Sardar and Hisar Surkha.

\section{Nutritional content of guava chutney}

\section{Proximate composition}

The nutritional evaluation of the chutneys was carried out, which showed a significant difference with respect to the cultivars. The moisture, protein, fiber, ash and carbohydrate content of the chutneys were found to vary significantly however, insignificant difference was found in the fat content (Table 1). The moisture content ranged from 27.73 - 35.19 $\%$. Chutney developed from Sardar variety had maximum moisture (35.19\%) followed by Lalit (33.49\%) whereas, the lowest moisture was present in chutney made from Punjab Pink (27.73\%). The moisture content of the chutneys were comparable to that of the fruit jams which have been reported to contain $31.23-33.36 \%$ moisture (Naeem et al., 2017) Generally, the moisture content of foods can be used as an indicator of its shelf life (Fellows, 2000). Low moisture content indicates that the chutneys have a long shelf life.

Crude protein content among the chutneys varied from $0.16-0.26 \%$ with highest protein content in chutney prepared from Lalit 
variety $(0.26 \%)$, followed by Punjab Pink $(0.23 \%)$ and Hisar Safeda (0.22\%) whereas, chutney from Sardar was found to have least protein content (0.16\%). Sahni (1997) reported 0.58 to $0.68 \%$ protein in amla chutney developed from four different varieties. Total ash content of the chutneys varied between $0.46-0.73 \%$. Highest ash content was found in Punjab Pink chutney $(0.73 \%)$, followed by Hisar Surkha $(0.68 \%)$ and the least amount of ash $(0.46 \%)$ was observed in chutney made from Shweta variety. The ash content was found to be higher in chutneys made from pink fleshed guavas which may be due to difference in ash content among the guava varieties.
All the chutneys had low fat content that was in the range $0.18-0.30 \%$. It was reported that guavas have very low fat of $0.2-0.3 \%$ (Gopalan et al., 2004) which explains the lack of fat detected in chutneys for this study. The crude fiber was found to be between 1.23 $2.49 \%$, being highest $(2.49 \%)$ in chutney developed from Punjab Pink variety and least (1.23\%) in Lalit.

This variation might have been associated with the variation in the treatments i.e. addition of the ginger and garlic into it, which might have contributed to the slight increase in the fiber content and also due to the varietal differences.

Table.1 Proximate composition of chutney developed from different varieties of guava (DW basis)

\begin{tabular}{|l|c|c|c|c|c|c|}
\hline Varieties & $\begin{array}{c}\text { Moisture } \\
(\%)\end{array}$ & $\begin{array}{c}\text { Crude } \\
\text { Protein (\%) }\end{array}$ & $\begin{array}{c}\text { Crude } \\
\text { Fat (\%) }\end{array}$ & $\begin{array}{c}\text { Crude } \\
\text { Fiber (\%) }\end{array}$ & $\begin{array}{c}\text { Total Ash } \\
(\%)\end{array}$ & $\begin{array}{c}\text { Carbohydrates } \\
(\%)\end{array}$ \\
\hline White Fleshed Varieties \\
\hline Sardar & $35.19^{\mathrm{a}} \pm 0.19$ & $0.16^{\mathrm{b}} \pm 0.01$ & $0.30 \pm 0.07$ & $2.21^{\mathrm{ab}} \pm 0.04$ & $0.51^{\mathrm{c}} \pm 0.04$ & $61.74^{\mathrm{d}} \pm 0.24$ \\
\hline Shweta & $32.58^{\mathrm{b}} \pm 1.28$ & $0.19^{\mathrm{ab}} \pm 0.01$ & $0.28 \pm 0.02$ & $1.96^{\mathrm{bc}} \pm 0.05$ & $0.46^{\mathrm{d}} \pm 0.02$ & $64.58^{\mathrm{bcd}} \pm 1.29$ \\
\hline Hisar Safeda & $29.27^{\mathrm{cc}} \pm 0.98$ & $0.22^{\mathrm{ab}} \pm 0.02$ & $0.23 \pm 0.08$ & $1.65^{\mathrm{c}} \pm 0.11$ & $0.59^{\mathrm{bc}} \pm 0.04$ & $68.18^{\mathrm{ab}} \pm 0.93$ \\
\hline Pink Fleshed Varieties \\
\hline Lalit & $33.49^{\mathrm{ab}} \pm 0.35$ & $0.26^{\mathrm{a}} \pm 0.02$ & $0.27 \pm 0.01$ & $1.23^{\mathrm{d}} \pm 0.06$ & $0.63^{\mathrm{b}} \pm 0.02$ & $64.26^{\mathrm{cd}} \pm 0.64$ \\
\hline Punjab Pink & $27.73^{\mathrm{d}} \pm 0.73$ & $0.23^{\mathrm{ab}} \pm 0.01$ & $0.18 \pm 0.01$ & $2.49^{\mathrm{a}} \pm 0.12$ & $0.73^{\mathrm{a}} \pm 0.03$ & $68.79^{\mathrm{a}} \pm 0.81$ \\
\hline Hisar Surkha & $30.73^{\mathrm{bcd}} \pm 0.31$ & $0.20^{\mathrm{ab}} \pm 0.02$ & $0.21 \pm 0.02$ & $1.86^{6 \mathrm{cc}} \pm 0.03$ & $0.68^{\mathrm{ab}} \pm 0.03$ & $66.46^{\mathrm{ab}} \pm 0.31$ \\
\hline
\end{tabular}

Values are given as Mean \pm SE

Figures with different superscripts are significantly different $(p<0.05)$

Table.2 Mineral content of the guava chutneys

\begin{tabular}{|l|c|c|c|}
\hline Varieties & $\begin{array}{c}\text { Calcium } \\
(\mathbf{m g} / \mathbf{1 0 0} \text { g) }\end{array}$ & $\begin{array}{c}\text { Phosphorus } \\
(\mathbf{m g} / \mathbf{1 0 0} \mathbf{g})\end{array}$ & $\begin{array}{c}\text { Potassium } \\
(\mathbf{m g} / \mathbf{1 0 0} \mathbf{g})\end{array}$ \\
\hline White Fleshed Varieties \\
\hline Sardar & $8.31^{\mathrm{a}} \pm 0.17$ & $15.20^{\mathrm{c}} \pm 0.07$ & $48.30^{\mathrm{b}} \pm 0.51$ \\
\hline Shweta & $7.45^{\mathrm{ab}} \pm 0.28$ & $16.46^{\mathrm{abc}} \pm 0.22$ & $41.61^{\mathrm{d}} \pm 0.89$ \\
\hline Hisar Safeda & $6.73^{\mathrm{ab}} \pm 0.08$ & $18.53^{\mathrm{a}} \pm 0.17$ & $39.07^{\mathrm{d}} \pm 0.21$ \\
\hline Pink Fleshed Varieties \\
\hline Lalit & $7.94^{\mathrm{a}} \pm 0.05$ & $15.89^{\mathrm{bc}} \pm 0.03$ & $46.54^{\mathrm{bc}} \pm 0.42$ \\
\hline Punjab Pink & $6.17^{\mathrm{ab}} \pm 0.12$ & $17.91^{\mathrm{b}} \pm 0.27$ & $53.45^{\mathrm{a}} \pm 1.66$ \\
\hline Hisar Surkha & $5.63^{\mathrm{b}} \pm 0.06$ & $17.45^{\mathrm{ab}} \pm 0.33$ & $43.39^{\mathrm{cd}} \pm 1.28$ \\
\hline
\end{tabular}

Values are given as Mean \pm SE

Figures with different superscripts are significantly different $(p<0.05)$ 
Table.3 Vitamin C and total carotenoid content of guava chutneys made from different varieties

\begin{tabular}{|l|c|c|}
\hline Varieties & $\begin{array}{c}\text { Vitamin C } \\
(\mathbf{m g} / \mathbf{1 0 0} \mathbf{g})\end{array}$ & $\begin{array}{c}\text { Total Carotenoids } \\
(\mathbf{m g} / \mathbf{1 0 0} \text { g) }\end{array}$ \\
\hline White Fleshed Varieties & $21.83^{\mathrm{a}} \pm 0.37$ & $0.77^{\mathrm{c}} \pm 0.19$ \\
\hline Sardar & $13.33^{\mathrm{c}} \pm 0.22$ & $0.56^{\mathrm{c}} \pm 0.13$ \\
\hline Shweta & $18.78^{\mathrm{b}} \pm 0.12$ & $0.51^{\mathrm{c}} \pm 0.08$ \\
\hline Hisar Safeda & $3.2^{\mathrm{ab}} \pm 0.20$ \\
\hline Pink Fleshed Varieties & $17.62^{\mathrm{b}} \pm 0.08$ & $3.80^{\mathrm{a}} \pm 0.11$ \\
\hline Lalit & $14.25^{\mathrm{c}} \pm 0.73$ & $2.7^{\mathrm{b}} \pm 0.17$ \\
\hline Punjab Pink & $14.95^{\mathrm{c}} \pm 0.28$ & \\
\hline Hisar Surkha &
\end{tabular}

Values are given as Mean \pm SE

Figures with different superscripts are significantly different $(p<0.05)$

Carbohydrate content being highest $(68.79 \%)$ in the chutney prepared from Punjab Pink, ranged from $61.74-68.79 \%$ among the chutneys. High carbohydrate content in chutneys can be associated with the addition of large amount of sugar. Chauhan et al., (1994) observed $45.6 \%$ carbohydrate to be present in wild pomegranate chutney.

\section{Mineral content}

The results of the minerals that were estimated in the chutneys are presented in Table 2. Minerals such as potassium, calcium and phosphorus were found in appreciable amount in all the chutneys developed from different guava varieties. It may be attributed to the guava fruit pulp being a rich source of potassium and fair source of calcium and phosphorus. The potassium content in the chutneys was found to be between 39.07 $53.45 \mathrm{mg} / 100 \mathrm{~g}$. It was highest $(53.45 \mathrm{mg} / 100$ g) in chutney made from Punjab Pink variety, followed by Sardar $(48.30 \mathrm{mg} / 100 \mathrm{~g})$ and Lalit $(46.54 \mathrm{mg} / 100 \mathrm{~g})$. The lowest potassium content $(39.07 \mathrm{mg} / 100 \mathrm{~g})$ was observed in Hisar Safeda chutney. The phosphorus content was highest in chutney developed from Hisar Safeda $(18.53 \mathrm{mg} / 100 \mathrm{~g})$ whereas; least phosphorus $(15.20 \mathrm{mg} / 100 \mathrm{~g})$ was present in chutney from Sardar variety.
Calcium content among the chutneys varied between $5.63-8.31 \mathrm{mg} / 100 \mathrm{~g}$, being highest in chutney prepared from Sardar variety. Chutneys developed from other guava varieties also had fair amount of phosphorus and calcium.

\section{Vitamin C and total carotenoids}

The vitamin $\mathrm{C}$ and total carotenoid content of guava chutneys were as shown in Table 3 . The ascorbic acid in the chutneys was between $13.33-21.83 \mathrm{mg} / 100 \mathrm{~g}$. It was observed significantly higher in the chutney prepared from fruits of cultivar Sardar (21.83 $\mathrm{mg} / 100 \mathrm{~g}$ ) followed by Hisar Safeda (18.78 $\mathrm{mg} / 100 \mathrm{~g})$ and Lalit $(17.62 \mathrm{mg} / 100 \mathrm{~g})$. The least $(13.33 \mathrm{mg} / 100 \mathrm{~g})$ ascorbic acid content was in chutney prepared from Shweta. The high vitamin $\mathrm{C}$ level of the chutneys was desirable as this vitamin is vital in iron absorption as well as formation of intracellular protein collagen (Wardlaw et al., 2004). Sahni (1997) found that ascorbic acid content was quite high in amla chutney (195 to $253.8 \mathrm{mg} / 100 \mathrm{~g}$ ).

Total carotenoids found only in pink-fleshed guava were highest in chutney made from Punjab Pink $(3.80 \mathrm{mg} / 100 \mathrm{~g})$ followed by Lalit $(3.20 \mathrm{mg} / 100 \mathrm{~g})$ and Hisar Surkha $(2.70$ 
$\mathrm{mg} / 100 \mathrm{~g})$. Also, the chutneys from white fleshed guavas had carotenoid content in the range 0.51 to $0.77 \mathrm{mg} / 100 \mathrm{~g}$ which may be due to the spices present in the chutney. Miglio et al., (2008) found that ascorbic acid reduce significantly on cooking while the total carotenoid content increases slightly during cooking and boiling processes.

The study showed that chutneys developed from different guava varieties contained substantial amount of fiber, potassium, phosphorus, calcium, vitamin $\mathrm{C}$ and total carotenoids. With regard to the sensory qualities, chutneys prepared from Sardar and Hisar Surkha varieties were found to be most acceptable. Chutneys made from other varieties were also liked at various degrees. Therefore, inclusion of guava chutney in the daily diet can improve the nutritional quality together with adding variety to the diet. It will also help to reduce the post-harvest losses due to highly perishable nature of the guava fruits and thus extend their shelf life ensuring greater availability over time.

\section{Acknowledgement}

The authors are thankful to Indian Council of Agricultural Research for providing financial assistance in form of Junior Research Fellowship to conduct the study.

\section{References}

AOAC. 2000. Official Methods of Analysis. Association of Official Analytical Chemist $17^{\text {th }}$ Edition. Washington, DC.

AOVC. 1996. Methods of vitamin assay. Association of Vitamin Chemists Inc. (Ed.) Interscience Publishers. Pp. 306312.

Chauhan, S. K., Lal, B. B., and Sharma, R. 1994. Development of instant dehydrated wild pomegranate chutney. J. Food. Sci. Technol. 31(1): 58-59.
Fellows, P. J., 2000. Controlled or modified atmosphere storage and packaging. In: Food processing technology: principles and practice. Woodhead Publishing Limited, CRC Press, Cambridge.

Gopalan, C., Ramasastri, B.V. and Balasubramanian, S.C. 2004. Nutritive value of Indian Foods; National Institute of Nutrition (NIN). Indian Council of Medical Research, Hyderabad. Pp: 59-67.

Hassimotto, N. M. A., Genovese, M. I., and Lajolo, F. M. 2005. Antioxidant activity of dietary fruits, vegetables and commercial frozen fruit pulps. J. Agri. Food. Chem. 53(8): 2928-2935.

James, T. L., 1995. Nuclear magnetic resonance and nucleic acids: Methods in enzymology. Academic Press, New York, 644.

Joseph, B., and Priya, M. 2011. Review on nutritional, medicinal, and pharmacological properties of guava (Psidium Guajava L.). Int. J. Pharm. Biol. Sci., 2(1): 53-69.

Larmond, E., 1977. Method for sensory evaluation of food. Can. Deptt. Agric. Pubs. 1284, 36-37.

Miglio, C., Chiavaro, E., Visconti, A., Fogliano, V., and Pellegrini, N. 2008. Effects of different cooking methods on nutritional and physiochemical characteristics of selected vegetables. $J$. Agric. Food. Chem. 56: 139-147

Naeem, M. M.., Fairulnizal, M. M., Norhayati, M. K., Zaiton, A., Norliza, A. H., Syuriahti, W. W., Azerulazree, J. M., Aswir, A. R., and Rusidah, S. 2017. The nutritional composition of fruit jams in the Malaysian market. Journal of the Saudi Society of Agricultural Sciences. 16(1): 89-96

Piper, C. S., 1950. Soil and plant analysis. Interscience Publication, Inc. New York. Pp: 212.

Sahni, N., 1997. Physico chemical and 
organoleptic changes during preservation of amla products. M.Sc. Thesis, Punjab Agricultural University, Ludhiana, India.

Wardlaw, G. M., Hampl, J. S., and Diilvestro, R. A. 2004. Perspective in Nutrition. 6th ed. McGraw Hill, London.
Zakaria, H., Simpson, K., Brown, R. R., and Kvotwaire, A. 1979. Use of reversed phase HPLC analysis for the determination of pro vitamin A carotene in tomatoes. J. Chromatography. 176(1): 109-117.

\section{How to cite this article:}

Homi Joshi, A. Kochhar and Boora, R.S. 2017. Development and Quality Evaluation of Chutney from New Varieties of White and Pink-Fleshed Guava. Int.J.Curr.Microbiol.App.Sci. 6(10): 1062-1068. doi: https://doi.org/10.20546/ijcmas.2017.610.128 